\title{
Hydrogenation reactions of carbon on Earth: Linking methane, margarine, and life of
}

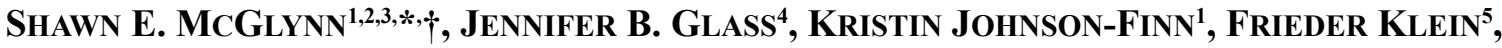 Sebastian A. SANDEN ${ }^{1,6}$, MatThew O. SChrenK ${ }^{7}$, Y UiChiro Ueno ${ }^{1}$, AND Alberto Vitale-Brovarone ${ }^{8,9}$}

\author{
${ }^{1}$ Earth-Life Science Institute, Tokyo Institute of Technology, Ookayama, Meguro, Tokyo 152-8550, Japan \\ ${ }^{2}$ Blue Marble Space Institute of Science, Seattle, Washington 98154, U.S.A. \\ ${ }^{3}$ Biofunctional Catalyst Research Team, RIKEN Center for Sustainable Resource Science, Wako-shi 351-0198, Japan \\ ${ }^{4}$ School of Earth and Atmospheric Sciences, Georgia Institute of Technology, Atlanta, Georgia 30332, U.S.A. \\ ${ }^{5}$ Department of Marine Chemistry and Geochemistry, Woods Hole Oceanographic Institution, Woods Hole, Massachusetts 02543, U.S.A. \\ ${ }^{6}$ Department of Chemical Science and Engineering, School of Materials and Chemical Technology, Tokyo Institute of Technology, Tokyo, Japan \\ ${ }^{7}$ Department of Earth and Environmental Sciences, Michigan State University, East Lansing, Michigan 48824, U.S.A. \\ ${ }^{8}$ Sorbonne Université, Muséum National d'Histoire Naturelle, UMR CNRS 7590, IRD, Institut de Minéralogie, \\ de Physique des Matériaux et de Cosmochimie, IMPMC, 75005, Paris, France \\ ${ }^{9}$ Dipartimento di Scienze della Terra, Università degli Studi di Torino, 10125 Torino, Italy
}

\begin{abstract}
Hydrogenation reactions are a major route of electron and proton flow on Earth. Interfacing geology and organic chemistry, hydrogenations occupy pivotal points in the Earth's global geochemical cycles. Some examples of hydrogenation reactions on Earth today include the production and consumption of methane in both abiotic and biotic reactions, the reduction of protons in hydrothermal settings, and the biological synthesis and degradation of fatty acids. Hydrogenation reactions were likely important for prebiotic chemistry on the early Earth, and today serve as one of the fundamental reaction classes that enable cellular life to construct biomolecules. An understanding and awareness of hydrogenation reactions is helpful for comprehending the larger web of molecular and material inter-conversions on our planet. In this brief review we detail some important hydrogenation and dehydrogenation reactions as they relate to geology, biology, industry, and atmospheric chemistry. Such reactions have implications ranging from the suite of reactions on early Earth to industrial applications like the production of hydrocarbon fuel.
\end{abstract}

Keywords: Hydrogenation, hydrogen, methane, carbon dioxide, carbon monoxide, redox, reduction, oxidation; Earth in Five Reactions: A Deep Carbon Perspective

\section{INTRODUCTION}

Hydrogenation is defined as reduction of a substrate (organic or mineral) by addition of hydrogen. This review surveys some of the key geochemical hydrogenation reactions of carbon on Earth where such reactions are widespread. Deep in the Earth's interior, at high temperatures and pressures, these reactions play important roles in controlling the long-term redox state of the planet. Hydrogenation could have played a role in prebiotic chemistry on the ancient Earth through precursor reactions akin to the reactions enable cellular today. Hydrogenation reactions have been of industrial importance since their discovery, finding wide applications ranging from the production of margarine to the use of solar driven $\mathrm{CO}_{2}$ reduction to form petroleum and in liquid fuel technologies. Although the focus of this review will be carbon hydrogenations, we note that other substrates, such as oxygen, sulfate, and nitrogen gas, are also hydrogenated and dehydrogenated in nature. Table 1 shows a few examples. A more complete tabulation of hydrogenation reactions in biology

\footnotetext{
*E-mail: mcglynn@elsi.jp; Orcid 0000-0002-8199-7011.

of Open access: Article available to all readers online. This article is CC-BY-NC-ND. $\dagger$ Special collection papers can be found online at http://www.minsocam.org/MSA/ AmMin/special-collections.html.
}

is available in Tables 13 and 14 in Thauer et al. (1977), and a recent review on some topics discussed here has recently appeared (Preiner et al. 2018).

\section{WHAT IS A HYDROGENATION REACTION?}

The hydrogen involved in a hydrogenation reaction can either come in the form of hydride $\left(\mathrm{H}^{-}\right)$, or the hydrogen atom $(\mathrm{H})$, and is often accompanied by proton addition $\left(\mathrm{H}^{+}\right)$. Hydrogenation reactions are categorized by the source of electrons and protons. When molecular hydrogen $\left(\mathrm{H}_{2}\right)$ is the source of electrons and protons, as is often the case in both geology and industry, the reaction is simply known as "hydrogenation." When another molecule is the source of electrons and protons, as is often the case in biology, the reaction is known as "transfer hydrogenation." In the reverse direction, a hydrogenation reaction is referred to as a dehydrogenation.

Several relevant hydrogenation reactions are shown in Figure 1, which illustrates two pathways of $\mathrm{CO}_{2}$ reduction $(\mathrm{C}-1$ reactions) as they exist in, and out of biology, as well as some hydrogenation reactions involving more than one carbon atom. Geologic hydrogenation reactions commonly involve simple inorganic oxidized carbon compounds, such as carbon monoxide $(\mathrm{CO})$ and carbon dioxide $\left(\mathrm{CO}_{2}\right)$, which react with $\mathrm{H}_{2}$ to 
TABLE 1. Some hydrogenation/dehydrogenation reactions of biogeochemical importance involving carbon, nitrogen, and sulfur, written as redox half reactions

\begin{tabular}{|c|c|c|c|c|}
\hline Reaction & Abiotic path & References & Biotic path & References \\
\hline $\mathrm{N}_{2}+6 \mathrm{e}^{-}+6 \mathrm{H}^{+} \rightleftarrows 2 \mathrm{NH}_{3}$ & $\begin{array}{l}\text { Lightning, some } \\
\text { reduced minerals }\end{array}$ & $\begin{array}{l}\text { (Brandes et al. 1998; Schoonen and } \\
\text { Xu 2001; Smirnov et al. 2008) }\end{array}$ & Nitrogenase & (Bulen and LeComte 1966) \\
\hline $\mathrm{CO}_{2}+8 \mathrm{e}^{-}+8 \mathrm{H}^{+} \rightleftarrows \mathrm{CH}_{4}+2 \mathrm{H}_{2} \mathrm{O}$ & $\begin{array}{l}\text { Carbonate } \\
\text { methanation }\end{array}$ & $\begin{array}{l}\text { (Giardini and Salotti 1969; } \\
\text { Reller et al. 1991; Yoshida et al. 1999) }\end{array}$ & $\begin{array}{l}\text { Methanogenesis/ } \\
\text { methane oxidation }\end{array}$ & $\begin{array}{c}\text { (Hoehler et al. 1994; } \\
\text { Thauer et al. 2008; Thauer 2010) }\end{array}$ \\
\hline $\mathrm{CO}_{2}+2 \mathrm{e}^{-}+2 \mathrm{H}^{+} \rightleftarrows \mathrm{HCOOH}$ & Reduced minerals & (Beller and Bornscheuer 2014) & Formate dehydrogenase & (Ferry 1990; Maia et al. 2017) \\
\hline $\mathrm{SO}_{4}^{-2}+8 \mathrm{e}^{-}+9 \mathrm{H}^{+} \rightleftarrows \mathrm{HS}^{-}+4 \mathrm{H}_{2} \mathrm{O}$ & $\begin{array}{l}\text { High temperature, } \\
\text { reduced minerals }\end{array}$ & $\begin{array}{c}\text { (Goldstein and } \\
\text { Aizenshtat 1994) }\end{array}$ & Sulfate reduction & $\begin{array}{c}\text { (Barton 1995; } \\
\text { Bartonand Fauque 2009) }\end{array}$ \\
\hline $\mathrm{O}_{2}+4 \mathrm{e}^{-}+4 \mathrm{H}^{+} \rightleftarrows 2 \mathrm{H}_{2} \mathrm{O}$ & & & Microbial lithotrophy & (Kawasumi et al. 1980; Spear et al. 2005) \\
\hline
\end{tabular}

FIGURE 1. A broad overview of hydrogenation reactions of carbon discussed in the text. $\mathrm{CO}_{2}$ reduction pathways encountered in methanogenesis and electroreduction on metal surfaces are shown on the right and left. Only the two electron reduction steps in the biological methanogenesis pathway are pictured on the right, including methanofuran (MFR) with a bound formyl-moeity and various states of carbon bound to the cofactor tetrahydromethanopterin $\left(\mathrm{H}_{4} \mathrm{MPT}\right)$ are shown. For more detail of the enzymology, the reader is guided to excellent reviews (Thauer 1998; Thauer et al. 2008). On the left, one example of an electrochemical carbon reduction pathway is shown; in this case the reduction arrow steps are one electron reduction steps, which can diverge in their composition depending on the metal surfaces and the final products, e.g., ethylene or methanol (Nie et al. 2013). In the center, some typical hydrogenation reactions encountered in organisms and abiotically propagate from pyruvate. From left to right below pyruvate are pictured the reduction of alkenes, the reduction of $\mathrm{NAD}$, and the reductive amination of pyruvate to the amino acid alanine.

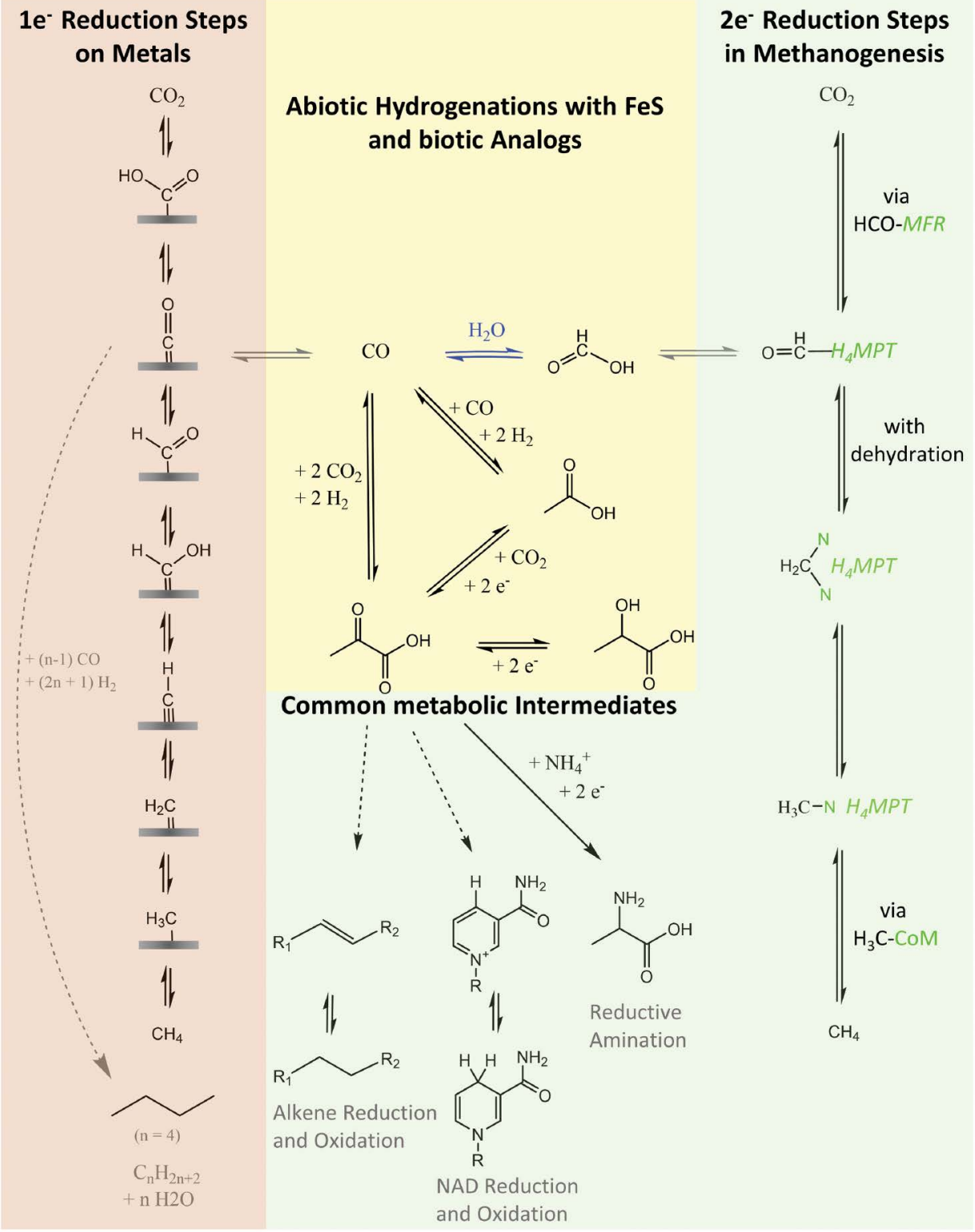

form simple reduced carbon compounds, such as methane $\left(\mathrm{CH}_{4}\right.$; "methanation") or formate $\left(\mathrm{HCO}_{2}^{-}\right)$. Biological enzymes enhance hydrogenation reaction rates by several orders of magnitude. Intriguingly, some of these enzymes use the same metals that facilitate catalysis of the abiotic reaction, such as nickel and iron. Biology also uses transfer hydrogenation reactions to syn- thesize substrates into sugars, fatty acids, and amino acids, using biological cofactors such as nicotinamide adenine dinucleotide (NADH), flavin adenine dinucleotide (FAD), or the iron-sulfur protein ferredoxin as electron releasing reductants instead of $\mathrm{H}_{2}$.

Rather than only being hydrogenated themselves, carbon compounds can also act as hydrogen donors. For example, the 
common reductants formic acid and isopropanol can hydrogenate other molecules via transfer hydrogenation, resulting in the formation of $\mathrm{CO}_{2}$ and acetone, respectively. If the hydrogenation is written as the reduction of an alkene ( $\mathrm{R}-\mathrm{CH}=\mathrm{CH}-\mathrm{R})$ to an alkane ( $\left.\mathrm{R}-\mathrm{CH}_{2}-\mathrm{CH}_{2}-\mathrm{R}\right)$, then in general some species $\left(\mathrm{DH}_{2}\right)$ will act as the hydrogen donor. In this formulation, $\mathrm{R}$ represents a carbon with unspecified bonding partners, and each line indicates a covalent bond. An example of a hydrogenation reaction is shown below where a carbon-carbon double bond is reduced.

$$
\mathrm{DH}_{2}+\mathrm{R}-\mathrm{CH}=\mathrm{CH}-\mathrm{R} \rightleftarrows \mathrm{R}-\mathrm{CH}_{2}-\mathrm{CH}_{2}-\mathrm{R}+\mathrm{D} .
$$

The reduction of oxidized fatty acids to margarine is a wellknown example of hydrogenation of alkenes to alkanes, where molecular hydrogen $\left(\mathrm{H}_{2}\right)$ is used as the reductant, and the kinked double bonds in alkene fats are converted to more linear alkanes, the so-called saturated fats, which have a greater tendency to gel at room temperature.

\section{SERPENTINIZATION: A GEOLOGICAL FACILITATOR OF HYDROGENATION}

Over the past two decades there has been a profound rise in appreciation of the importance of serpentinization in generating $\mathrm{H}_{2}$ in a wide range of environmental settings and conditions (see Box 1). The reducing conditions created by serpentinization can facilitate the hydrogenation of dissolved inorganic compounds,

\section{Box 1: Serpentinization 101}

The alteration of magnesium- and iron-rich rocks by water is commonly referred to as "serpentinization." This process turns a dry, dense, mechanically strong, and reduced rock into a hydrous, significantly less dense, mechanically weak, and strongly oxidized rock mainly composed of serpentine-group minerals. Serpentinization is widespread in marine environments and occurs at mid-ocean ridges, at ridge flanks and fracture zones, at magma-poor rifted plate margins, and in forearc settings of subduction zones. Serpentinization is evident in Archean rocks (komatiites), suggesting that it has been going on throughout most of Earth's history. Notably, there is evidence from meteorites and remote sensing for serpentinization beyond Earth. The oxidation of iron by water generates molecular hydrogen, which, as a byproduct of serpentinization, is of central importance for hydrogenotrophic microorganisms and the abiotic hydrogenation of carbon compounds to form hydrocarbons.

Hydrogen produced during serpentinization can facilitate the abiotic formation of $\mathrm{CH}_{4}$ and other hydrocarbons via hydrogenation of $\mathrm{CO}_{2}$. Indeed, vent fluids associated with serpentinization of ultramafic rocks at mid-ocean ridges are commonly enriched in $\mathrm{CH}_{4}$ and other short-chain hydrocarbons (Charlou et al. 2002; Proskurowski et al. 2008; McDermott et al. 2015; Lang et al. 2018; Johnson et al. 2015). However, the pathways and conditions of abiotic synthesis reactions remain incompletely understood. such as $\mathrm{CO}_{2}, \mathrm{SO}_{4}^{2-}$, and $\mathrm{NO}_{3}^{-}$. Hydrogen production, here portrayed in a simplified and generalized reaction

$$
2 \mathrm{FeO}+\mathrm{H}_{2} \mathrm{O} \rightleftarrows \mathrm{Fe}_{2} \mathrm{O}_{3}+\mathrm{H}_{2}
$$

is tied to the oxidation of ferrous to ferric iron by water. In the above reaction, $\mathrm{FeO}$ represents the ferrous iron component in olivine and pyroxene, and $\mathrm{Fe}_{2} \mathrm{O}_{3}$ represents the ferric iron component in product minerals. While the distribution and valence of iron among serpentine-group minerals (lizardite, chrysotile, antigorite), as well as other minor minerals (e.g., magnetite, brucite, and talc) (control the production of $\mathrm{H}_{2}$. The stability and composition of these minerals depends on protolith composition, alteration temperature, reaction kinetics, and composition of the reactant fluid. Thermodynamic reaction path models are useful to assess how mineral and rock composition affects $\mathrm{H}_{2}$ production (e.g., McCollom and Bach 2009; Klein et al. 2013). These models suggest that the production of $\mathrm{H}_{2}$ during serpentinization of peridotite, the most common ultramafic rock type in Earth's upper mantle, peaks at temperatures of $\sim 300-320^{\circ} \mathrm{C}$. At higher temperatures, olivine is part of the equilibrium mineral assemblage, which limits the amount of oxidizable iron available for $\mathrm{H}_{2}$ generation. At lower temperatures, the amount of oxidizable iron available for $\mathrm{H}_{2}$ generation is limited by preferential partitioning of ferrous iron in brucite. Hydrothermal laboratory experiments support these findings, however, they highlight that reaction kinetics and hydrodynamic properties must be taken into account to evaluate the underlying processes of serpentinization and associated $\mathrm{H}_{2}$ production (Martin and Fyfe 1970; Allen and Seyfried 2003; Malvoisin and Brunet 2014; Klein et al. 2015; Lamadrid et al. 2017; Syverson et al. 2017; Escario et al. 2018).

\section{ABIOTIC SYNTHESIS OF HYDROCARBONS}

In catalyzed reactions, methane can be formed through hydrogenation reactions, for example:

$$
\begin{aligned}
& \mathrm{CO}_{2}+4 \mathrm{H}_{2} \rightleftarrows \mathrm{CH}_{4}+2 \mathrm{H}_{2} \mathrm{O} \\
& \mathrm{CO}+3 \mathrm{H}_{2} \rightleftarrows \mathrm{CH}_{4}+\mathrm{H}_{2} \mathrm{O} .
\end{aligned}
$$

These reactions have been the focus of extensive research and technological development in chemical engineering since discovery (Sabatier and Senderens 1902; Rönsch et al. 2016).

Related to the $\mathrm{CH}_{4}$ forming Sabatier process (Reaction 3 above) is the Fischer-Tropsch type of reaction that produces a range of abiotic hydrocarbons via hydrogenation of $\mathrm{CO}$ with $\mathrm{H}_{2}$. This process can be generalized by the reaction:

$$
(2 \mathrm{n}+1) \mathrm{H}_{2}+\mathrm{nCO} \rightleftarrows \mathrm{C}_{\mathrm{n}} \mathrm{H}_{2 \mathrm{n}+2}+\mathrm{nH}_{2} \mathrm{O} .
$$

The relative abundance of $\mathrm{CH}_{4}, \mathrm{C}_{2} \mathrm{H}_{6}, \mathrm{C}_{3} \mathrm{H}_{8}$, and other compounds follows a probabilistic distribution of molecular lengths, termed the Anderson-Schulz-Flory distribution (Anderson 1978). Together, methanation and the Fischer-Tropsch type processes have been suggested to explain the origin of $\mathrm{CH}_{4}$ and other hydrocarbons, however mass balance and stable and radiogenic isotope constraints suggest that dissolved inorganic carbon is not reduced to $\mathrm{CH}_{4}$ during convection of hydrothermal fluids $(\mathrm{McDermott}$ et al. 2015). Accordingly, $\mathrm{CH}_{4}$ formation is likely decoupled from 
convecting fluids and may occur, for instance, in fluid inclusions as one of us has recently suggested (Klein et al. 2019).

Regarding interconversions of small carbon compounds in hydrothermal fluids, methane formation occurs without mineral catalysts (Seewald et al. 2006), but the reactions are sluggish, in particular at low temperatures (McCollom 2016). For methanation to be more effective in an aqueous environment, catalysts are needed, often including nickel (Gadalla and Bower 1988; Horita and Berndt 1999; Miao et al. 2016). In these conditions several mechanisms may be possible (Fig. 2). Under hydrothermal conditions, the uncatalyzed reduction of $\mathrm{CO}_{2}$ to methanol $\left(\mathrm{CH}_{3} \mathrm{OH}\right)$ proceeds via a stepwise sequence of reactions that involve the formation of formic acid ( $\mathrm{HCOOH}), \mathrm{CO}$, and possibly formaldehyde $\left(\mathrm{CH}_{2} \mathrm{O}\right)$, as intermediary reaction products (Seewald et al. 2006). However, kinetic barriers appear to inhibit the reduction of $\mathrm{CH}_{3} \mathrm{OH}$ to $\mathrm{CH}_{4}$ and allow the reaction intermediaries to accumulate in solution at high concentrations reaching metastable thermodynamic equilibrium (Seewald et al. 2006). Indeed, formate appears to form on short timescales during mixing of reducing hydrothermal fluids with seawater, whereas the formation of $\mathrm{CH}_{4}$ may take thousands of years (Lang et al. 2012; McDermott et al. 2015).

Methane formation appears to be significantly more efficient in the presence of a vapor phase (McCollom 2016). The preferred interpretation for this observation is that abiotic $\mathrm{CH}_{4}$ synthesis is promoted by the presence of $\mathrm{a}_{2}$ vapor phase in direct contact with catalytic mineral surfaces without the interference of water molecules. In reaction fronts in serpentinizing environments, $\mathrm{H}_{2} \mathrm{O}$ consumption and $\mathrm{H}_{2}$ production from serpentinization can lead to $\mathrm{H}_{2}$ exsolution into a vapor phase, at least at low pressures, as indicated by pentlandite-awaruite-magnetite assemblages found in partially serpentinized rocks (Klein and Bach 2009). Although methanation of $\mathrm{CO}_{2}$ in a strongly reducing vapor phase seems feasible under specific conditions, radiocarbon data and mass balance constraints suggest that methanation of $\mathrm{CO}_{2}$ is relatively inefficient during hydrothermal circulation. Alternatively, abiotic $\mathrm{CH}_{4}$ can be leached from rock surfaces (Welhan 1988) or fluid inclusions (McDermott et al. 2015; McCollom 2016; Wang et al. 2018; Klein et al. 2019). Indeed, Klein et al. (2019) examined 160 olivine-bearing gabbros and peridotites from a wide range of geologic settings and found $\mathrm{H}_{2}$ and abiotic $\mathrm{CH}_{4}$ coexisting with serpentine, brucite, and magnetite within olivine-hosted secondary fluid inclusions in most of their samples. They estimated that fluid inclusions may store as much as $5 \mathrm{Pg}$ of $\mathrm{CH}_{4}$ in oceanic crust and mantle formed at slow and ultraslow spreading ridges. The proposed pathways of $\mathrm{CH}_{4}$ formation in olivine-hosted fluid inclusions is as follows: Carbon-bearing aqueous fluids are trapped as secondary inclusions in olivine between $\sim 800$ and $400{ }^{\circ} \mathrm{C}$ and react with their olivine host upon cooling below $340{ }^{\circ} \mathrm{C}$, which results in the formation of serpentine, brucite, magnetite, and $\mathrm{H}_{2}$. The production of $\mathrm{H}_{2}$ and concomitant consumption of liquid water by precipitation of hydrous minerals inside the inclusion creates conditions conducive to $\mathrm{CO}_{2}$ reduction to $\mathrm{CH}_{4}$. While $\mathrm{CH}_{4}$ and $\mathrm{H}_{2}$ can be stored over geological timescales within these inclusions, gases can be released during dissolution or fracturing of the olivine host. Remarkably, the stable isotope compositions of $\mathrm{CH}_{4}$ in vent fluids emanating from mafic- and ultramafic-hosted hydrothermal systems are virtually indistinguishable, calling for a common underlying process of $\mathrm{CH}_{4}$ formation (Wang et al. 2018). Because $\mathrm{CH}_{4}$-rich secondary fluid inclusions occur in olivine-bearing mafic and ultramafic rocks, they represent a common source of abiotic $\mathrm{CH}_{4}$ in both mafic- and ultramafic-hosted hydrothermal systems (Klein et al. 2019).

Collectively, abiotic hydrocarbon formation comprises a substantial carbon flow in submarine hydrothermal systems, continental gas seeps and alkaline springs, and even on other planetary bodies such as Mars and Enceladus (Horita and Berndt 1999; Charlou et al. 2002; Etiope and Sherwood Lollar 2013; Klein et al. 2019).

\section{OTHER GEOLOGIC CONTEXTS: HYDROGENATION OF INORGANIC METAL CARBONATE}

Interaction between metal carbonate minerals and $\mathrm{H}_{2}$ as shown in Equation 6 may represent an important process in planetary sciences, yet it remains poorly investigated under geological conditions. A comprehensive review on the subject was recently published (Lux et al. 2018).

$$
\mathrm{MeCO}_{3}+4 \mathrm{H}_{2} \rightleftarrows \mathrm{MeO}+\mathrm{CH}_{4}+2 \mathrm{H}_{2} \mathrm{O} \text {. }
$$

Experimental investigations have been conducted over a wide range of temperature conditions between 200 to $900{ }^{\circ} \mathrm{C}$, but most commonly at ambient pressure conditions, with the exception of the most recent studies reaching up to about 1.2 $\mathrm{MPa}$ (Baldauf-Sommerbauer et al. 2016). In a pure hydrogen atmosphere, hydrogenation may occur through different pathways as a function of several parameters including the amount and size of carbonate substratum, the nature of the metals involved, the presence of catalysts, temperature, and pressure. In the presence of water, hydrogenation can also happen as a result of thermal decomposition (Perry and Ahmad 1977; McCollom 2003; Tao
FIGURE 2. Two mechanisms for abiotic methanation. Top: associative pathway, whereby $\mathrm{C}-\mathrm{O}$ bond breaking is assisted by addition of $\mathrm{H}_{\text {ad. }}$. Bottom: dissociative pathway, whereby the $\mathrm{C}-\mathrm{O}$ bond is directly dissociated on the catalyst surface. Modified from Miao et al. (2016).

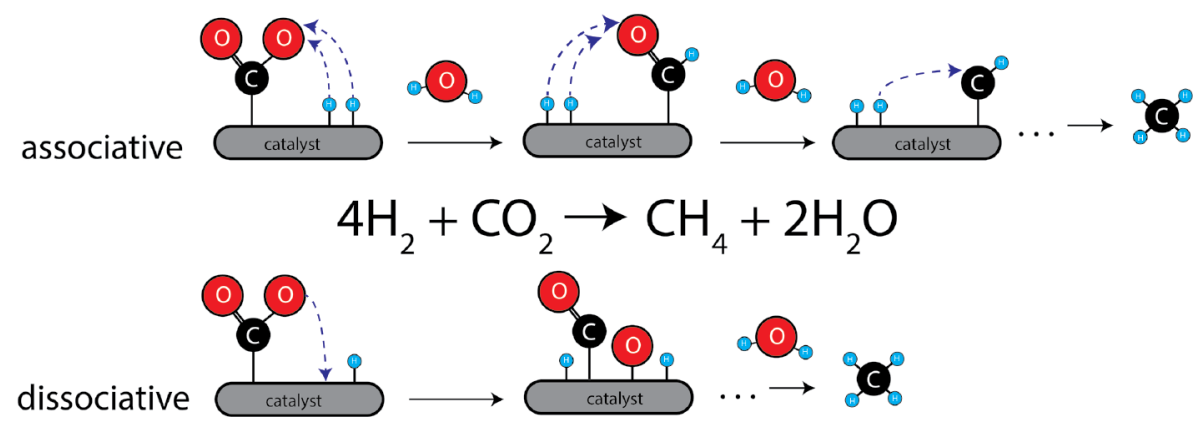


et al. 2018). In this case, ferrous iron in carbonate (siderite) is oxidized to ferric iron in magnetite, generating $\mathrm{H}_{2}$ from water that subsequently hydrogenates $\mathrm{CO}_{2}$ to organic compounds.

Although some experimental results appear contradictory (see review by Lux et al. 2018), the aforementioned parameters influence the amount and rates of carbonate decomposition, as well as on the speciation of the produced fluid phase, with large deviations from the general equation reported above. The most common alkaline-earth metal carbonates calcite and dolomite $\left(\mathrm{CaCO}_{3}, \mathrm{MgCO}_{3}\right)$ tend to produce $\mathrm{CO}_{2}$ and $\mathrm{CO}$ relative to $\mathrm{CH}_{4}$ or heavier hydrocarbons in the absence of catalysts such as $\mathrm{Ni}$, Ir, Pd, and Co (Padeste et al. 1991; Reller et al. 1991; Yoshida et al. 1999; Baldauf-Sommerbauer et al. 2016). Transition metal carbonates, such as siderite $\left(\mathrm{FeCO}_{3}\right)$, may produce $\mathrm{CH}_{4}$ during redox reactions involving $\mathrm{Fe}$, or the catalytic effect of native metal/oxides forming during the carbonate dissociation (Giardini and Salotti 1969; Reller et al. 1991; Tsuneto et al. 1992). Both direct carbonate methanation, i.e., direct surface-gas reaction between carbonate minerals and $\mathrm{H}_{2}$ to form light molecular weight hydrocarbons such as $\mathrm{CH}_{4}$, and methanation mediated through an intermediate $\mathrm{CO}_{2}-$ or $\mathrm{CO}+\mathrm{H}_{2}$ interaction have been documented (Lux et al. 2018).

Lux et al. (2018) discussed the potential industrial and environmental implications of metal carbonate hydrogenation. Manifestations of these reactions in natural systems are still barely documented. Lazar et al. (2014) discussed the possible implications of carbonate reduction on carbon mobility in subduction zones based on experimental results (2-10 kbar; 300$700{ }^{\circ} \mathrm{C}$ in aqueous fluids with changing $f_{\mathrm{O}_{2}}$ ) (Lazar et al. 2014). Giardini and Salotti (1969) and Salotti et al. (1971) discussed the potential role of this process on the abiotic formation of light hydrocarbons and solid organic C compounds in the Earth's crust and in carbonaceous chondrites (Giardini and Salotti 1969; Salotti et al. 1971). Similarly, carbonate methanation has been proposed as a possible mechanism to produce abiotic $\mathrm{CH}_{4}$ at relatively high-pressure conditions in subduction zones $(0.5-1 \mathrm{GPa}$; $\sim 400^{\circ} \mathrm{C}$ ) based on natural samples (Vitale Brovarone et al. 2017).

\section{Hydrogenation of reduced $\mathrm{C}$ phases in the deep Earth}

Hydrogenation/dehydrogenation reactions involving $\mathrm{H}_{2}$ and reduced $\mathrm{C}$ reservoirs, either solid (graphite, diamond, and carbides) or fluid (e.g., $\mathrm{CH}_{4}$ ), are also proposed to regulate recycling of $\mathrm{C}$ in the deep Earth. The equilibrium participation of elemental $\mathrm{C}, \mathrm{H}_{2}$, and $\mathrm{CH}_{4}$ is classically included among the reactions regulating fluid-rock equilibria involving $\mathrm{C}, \mathrm{O}$, and $\mathrm{H}$ in the so-called COH system (Deines 1980; Connolly 1995), following the reaction:

$$
\mathrm{CH}_{4} \rightleftarrows \mathrm{C}+2 \mathrm{H}_{2}
$$

For example, pyrolitic dissociation of $\mathrm{CH}_{4}$ to form graphite and $\mathrm{H}_{2}$ was proposed (Salotti et al. 1971) as a mechanism generating massive graphite deposits. The significance of this reaction in geological systems has been questioned based on the rarity of $\mathrm{H}_{2}$ rich fluids in geological systems (Rumble and Hoering 1986). The reverse reaction, the abiotic generation of $\mathrm{CH}_{4}$ through $\mathrm{C}$ hydrogenation, may occur in graphite-bearing metamorphosed ultramafic rocks percolated by $\mathrm{H}_{2}$-rich geological fluids (Vitale Brovarone et al. 2017), suggesting that reaction 7 may be achieved in nature. Furthermore, immiscibility of $\mathrm{H}_{2}$ in aqueous fluids at upper mantle conditions, as demonstrated by experimental results (Bali et al. 2013), may favor the geological occurrence of $\mathrm{H}_{2}$-mineral reactions (Griffin et al. 2018). The kinetics of graphite hydrogenation has been extensively investigated in material sciences at lowpressure conditions (Goethel and Yang 1988). In the deep Earth, the significance and kinetics of these reactions remain barely known. Hydrogenation/dehydrogenation of reduced $\mathrm{C}$ phases may extend to higher-pressure conditions and involve diamond or metal carbide precipitation/dissolution. The potential role of $\mathrm{CH}_{4}$ dehydrogenation on diamond formation through the latter reaction is known (Deines 1980) and might explain the origin of some $\mathrm{CH}_{4}$-deposited natural diamonds reported in the literature (Thomassot et al. 2007; Smit et al. 2016). Interactions between iron carbides and $\mathrm{H}^{+}$are also proposed to produce hydrocarbons (Lai 2007), but the significance of this reaction in deep terrestrial conditions remains unclear.

\section{Hydrogenations concerning iron carbonyls and metal sulfides with relevance to prebiotic chemistry}

Life as we know it links energy released during electron transfer reactions to cell activity, and hydrogenation reactions are a widespread mechanism of this. It has even been suggested that a primary role of life is to hydrogenate $\mathrm{CO}_{2}$ (Nitschke and Russell 2009). Before the formation of the first cells, hydrogenation reactions would have been important for the formation and interconversion of carbon molecules of intermediate redox states. Since $\mathrm{CO}_{2}$ reduction involves hydrogenation, it is required for all $\mathrm{CO}_{2}$-fixing life, and many reactions in modern metabolisms are either hydrogenation or dehydrogenation reactions. The same would likely be true of any early metabolism. Of relevance to primordial $\mathrm{CO}_{2}$ fixation, the hydrogenation of $\mathrm{CO}_{2}$ leading to formate/CO could represent a source of reduced carbon compounds, potentially present in geologic environments such as during volcanic outgassing into the deep sea (Cadle 1980). At $0.2 \mathrm{GPa}$ and $250{ }^{\circ} \mathrm{C}$, traces of pyruvic acid have been detected in laboratory experiments iron monosulfide (FeS) serving as the reductant (Cody et al. 2000). This reaction has been suggested to proceed through the formation of iron carbonyl complexes and subsequent reduction of $\mathrm{CO}$ with $\mathrm{H}_{2}$, which was produced through the oxidation of sulfide:

$$
\begin{aligned}
& 2 \mathrm{FeS}+6 \mathrm{CO}+2 \mathrm{RSH} \rightleftarrows \mathrm{Fe}_{2}(\mathrm{RS})_{2}(\mathrm{CO})_{6}+2 \mathrm{~S}^{0}+\mathrm{H}_{2} \\
& 3 \mathrm{CO}+2 \mathrm{H}_{2} \rightleftarrows \mathrm{C}_{3} \mathrm{H}_{4} \mathrm{O}_{3} .
\end{aligned}
$$

Huber and Wächtershauser showed that CO can react with methane thiol to form the "activated" thioester methyl-thioacetate $\left(\mathrm{CH}_{3} \mathrm{COSCH}_{3}\right)($ Huber and Wächtershäuser 1997), mimicking the biological process (for review, see Bender et al. 2011). They also showed that $\mathrm{CO}$ can form COS, which subsequently activates amino acids at the amine position, leading to their polymerization (Huber and Wächtershäuser 1998). It seems that hydrogenation of $\mathrm{CO}_{2}$ with $\mathrm{H}_{2}$ to form $\mathrm{CO}$ [which can equilibrate with formate $\left(\mathrm{HCO}_{2}^{-}\right)$through hydration] could be a powerful harbinger of reactions relevant to early life, and these hydrogenations may have been performed by the first cells (Russell and Martin 2004; Ferry and House 2006). 
C-C bond formation starting from $\mathrm{CO}_{2}$ can be achieved with suitable catalysts and electron donors at modest temperatures and pressures. Metallic iron has been shown to facilitate the reduction of $\mathrm{CO}_{2}$ to acetate with $E^{0 \prime}=-0.29 \mathrm{~V}$ (Thauer et al. 1977) vs. the standard hydrogen electrode (SHE) at pH 7 (He et al. 2010; Muchowska et al. 2017; Varma et al. 2018). But due to the lability of $\mathrm{Fe}^{0}$ forming less reducing iron species in water, it is important to consider how electrons might continually reduce $\mathrm{CO}_{2}$ with some specificity rather than simply reducing protons to $\mathrm{H}_{2}$ and exhausting the reducing potential supplied.

Serpentinizing systems in some situations may provide a constant supply of $\mathrm{H}_{2}$ and $\mathrm{HS}^{-}$that form iron sulfide mineral phases reminiscent of tetragonal FeS cluster found in redox active enzymes (Mielke et al. 2010). A hint of the importance of these FeS clusters might be found in a synthetic analog of the [2Fe2S] cofactor clusters found in contemporary biology, which has been shown to facilitate reductive carboxylations (Fig. 3) (Nakajima et al. 1975). This reaction relies on sodium hydrosulfite as a reductant with $E^{\prime} \sim-0.66 \mathrm{~V}$ vs. SHE at pH 7 (Mayhew 1978) and was observed in solutions of tetrahydrofuran, methanol, and water. Possibly linking soluble carbon chemistry with insoluble minerals, metal sulfides have been shown to reduce $\mathrm{CO}_{2}$ electrochemically (Yamaguchi et al. 2014; Kitadai et al. 2018). Figure 1 depicts schematically the reduction of $\mathrm{CO}_{2}$ to $\mathrm{CH}_{4}$ in one electron reduction steps on a metal electrode. Depending on the electrode material, the reduction steps below $\mathrm{CO}$ can branch off into the production of methanol or $\mathrm{C}_{2}$ compounds (Nie et al. 2013).

\section{A VERY BRIEF OVERVIEW OF HYDROGENATION IN BIOLOGY: ENERGY AND ANABOLISM}

Electron transfer reactions in the cell can be linked to respiratory processes, such as the hydrogenation of $\mathrm{O}_{2}$ or sulfate to produce water or $\mathrm{HS}^{-}$, respectively. In respiration, work is done as electrons move from a more negative potential to a more positive potential. In another mode of electron transfer that can involve hydrogenation reactions, a molecule can be reduced or oxidized as part of a biosynthetic pathway to construct a cell. In this case, the primary purpose is not energy harvesting, but bio-molecular construction, and biologists refer to this as anabolism.

In the case of $\mathrm{H}_{2}$, some organisms may oxidize it, and yet others may form it and release it. Whether $\mathrm{H}_{2}$ is consumed or produced in a metabolism is related to the thermodynamic tendency (i.e., electrochemical potential) of molecules other than hydrogen to acquire electrons from $\mathrm{H}_{2}$, or deliver them to protons. For example, if an organism is utilizing $\mathrm{O}_{2}$ as an electron acceptor in the presence of $\mathrm{H}_{2}$, there will be a tendency to pull

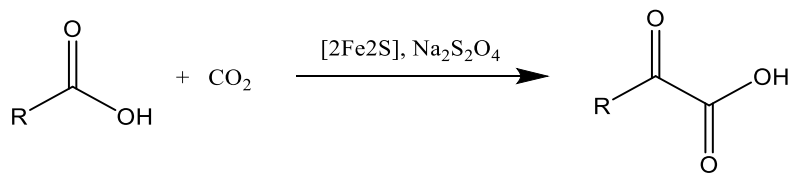

FIGURE 3. Reductive carboxylation of carboxylic acids as investigated by Nakajima et al. The reaction took place in $\mathrm{C} \mathrm{CO}_{2}$ saturated mixture of tetrahydrofuran, methanol, and water $(4: 2: 1)$ with sodium hydrosulfite as the reductant. [2Fe-2S] represents a two iron, two iron cluster, which is presumed catalyst of the reaction.

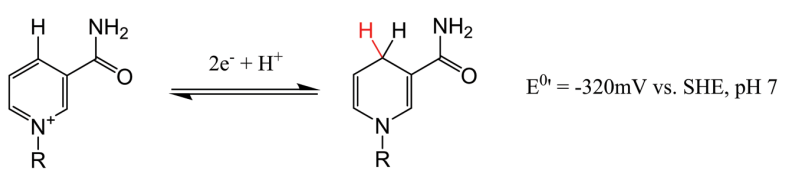

FIGURE 4. An example of biological transfer hydrogenation: nicotinamide adenine dinucleotide (NADH) can be reversibly oxidized and reduced, here shown as $\mathrm{NAD}^{+}$on the left, and NADH on the right.

electrons off of $\mathrm{H}_{2}$ and combine them with $\mathrm{O}_{2}$. Oxygen is such a powerful oxidant, that it "pulls" electrons from hydrogen even at non-measurable concentrations (Inskeep et al. 2005). To predict which direction electron transfer and hydrogenation reactions may occur it is useful to consider which molecules donate and accept electrons in and out of a given metabolism.

Many biological hydrogenations occur without the formation or consumption of $\mathrm{H}_{2}$. These are transfer hydrogenations, since they involve the gain or loss of hydrogen but do not directly involve $\mathrm{H}_{2}$ gas. For example, the ketone group of pyruvate can be reduced by two electrons to form the alcohol group of lactate (the reaction is illustrated in the center of Fig. 1). The electron donor and hydrogenating agent in the reaction may be the reduced form of the enzyme cofactor nicotinamide adenine dinucleotide (NADH), a biological two electron carrier (also shown in Fig. 1). This important electron carrier operates in biochemistry with the half cell reaction stoichiometry shown in Figure 4. Here the movement of the proton to and from nicotinamide adenine dinucleotide $\left(\mathrm{NAD}^{+}\right)$occurs in the form of a hydride $\left(\mathrm{H}^{-}\right)$. Other electron carriers such as flavin adenine dinucleotide (FAD) and the iron sulfur cluster containing protein ferredoxin operate in transfer hydrogenation reactions in the cell, and these molecules give cells a common electronic "currency."

\section{Case study: $\mathrm{CO}_{2}$ hydrogenation to formate}

In biology, $\mathrm{CO}_{2}$ is hydrogenated to formic acid $(\mathrm{HCOOH})$ by several enzymes, including the enzyme hydrogen-dependent carbon dioxide reductase (HDCR) (Schuchmann and Müller 2013) and formate dehydrogenase (FDH) (Appel et al. 2013) (Fig. 5). This reaction type of $\mathrm{CO}_{2}$ hydrogenation is the first in the carbon metabolism of the globally important methanogens and acetogens (Thauer 1998; Thauer et al. 2008; Schuchmann and Müller 2014), although instead of catalyzing the production of formate, the biological enzymes catalyze the formation of carbon complexed on an organic scaffold that is sequentially reduced in the cell (for review, see Maden 2000). These methane- and acetate-forming organisms live in anoxic environments and couple the exergonic reduction (hydrogenation) of $\mathrm{CO}_{2}$ to either methane or acetate to their growth. Interestingly, in reverse, acetate and methane can be used as metabolic fuel during anaerobic methane oxidation and anaerobic acetate oxidation depending on the availability of an electron acceptor of sufficient redox potential to make the net reactions favorable (Hattori 2008; Thauer 2011; McGlynn 2017).

Abiotic $\mathrm{CO}_{2}$ reduction to formate and other reduced carbon species is of substantial interest for sustainable chemistry goals (Gurudayal et al. 2017; Wei et al. 2017) and has been investigated extensively by electrochemical means (Hori 2008). In addition to electrochemically driven reactions, $\mathrm{CO}_{2}$ reduction to formate 


\section{Box 2: Energy Conservation in the Biological Cell 101}

All life requires energy for maintenance and replication. Biologists commonly refer to the process of cellular energy harvesting as "conservation." When they say this, they are not referring to the first law of thermodynamics! Energy conservation in biology refers to conversion; in the cell, it is about converting one form of energy to another. This conversion allows biology to temporarily capture energy, and divert it to cellular processes and functions. Biologists often consider "energy-rich" molecules such as adenosine triphosphate (ATP), though the energy "available" from these molecules is directly related to their concentration difference from that at equilibrium. In the case of ATP, the energy available is directly proportional to the concentrations of ATP and ADP, which are respectively the hydrolysis substrate, and product in the cell. ATP hydrolysis can be coupled to another chemical reaction that would otherwise be unfavorable.

Another form of "energy storage" or "energy harvesting" is by chemiosmosis, which involves coupling a chemical reaction to the movement of ions (often protons or sodium) across the membrane. Later, this offset in ion concentrations can be used to "push" a different reaction forward (for example, achieving a large offset in the concentration of ATP and ADP in the cell). In a classic and very valuable paper, Thauer et al. (1977) outlined how chemical potentials could be connected to cell growth and physiology.

How is all this connected to hydrogenation? All known life couples electron transfer reactions to maintenance and replication (often through ATP as an intermediate). Since hydrogenation is one of the basic routes of moving electrons from one molecule to another, they are of basic importance to biology. In the cell, electron transfer reactions such as hydrogenation can be linked, or coupled to other reactions that allow the cell to conserve energy and propagate.

In glycolysis, a central sugar metabolizing arm of metabolism, the intermediate glyceraldehyde 3-phosphate is oxidized and results in the formation of a phosphoester bond, which can be used subsequently to form ATP from ADP:
Glyceraldehyde-3Phosphate $+\mathrm{NAD}^{+}+$Phosphate $\rightleftarrows$ 1-3Bis-phosphoglycerate + NADH ATP

1,3-Bisphosphoglycerate + ADP $\rightleftarrows$ 3-Phosphoglycerate +

These reactions are examples of how hydrogenation and dehydrogenation reactions are coupled to energy harvesting; an aldehyde is dehydrogenated, making possible the formation of a phosphoester compound. This latter compound can then go on and drive reactions such as ATP formation, and ATP is used broadly as a contributor of exergonic chemical potential in reactions.

In addition to sugars, organisms also synthesize amino acids and fatty acids through hydrogenations; in reverse, these molecules are oxidized by dehydrogenation. In addition to the water soluble hydrogenations noted above, an important class of fat soluble biomolecules, such as quinones and methanophenazine, allow for electron and proton entry (and exit) into biological lipid membranes, by acting as agents of trans hydrogenation (for example, see Duszenko and Buan 2017). The ability to move charge into and across the membrane is one way that life accomplishes charge separation in chemiosmosis and temporarily captures energy for cellular processes, and again this example shows how critical hydrogenation reactions are in biological systems, which themselves are electronic. A basic schematic of one way biology uses these fat soluble transfer-hydrogenation reactions to build up a membrane spanning ion potential is shown in Figure 6. There, we can see a cartoon diagram of a cell membrane with two enzyme complexes embedded in the membrane. By having each enzyme catalyze a separate hydrogenation, and by sharing a common electronic intermediate (here drawn as " $\mathrm{Q} / \mathrm{QH}_{2}$," the cell is able to accomplish asymmetric charge movement across the membrane). This charge builds up and is later on utilizable in the form of an energy storage system in a process called "chemiosmosis." can take place at near ambient $P-T$ conditions with synthetic organometallic cofactors (e.g., Jószai and Joó 2007), or with natural minerals and metals at slightly higher $T-P$ conditions (see Methanation section above).

\section{Hydrogenations occurring in the atmosphere}

Hydrogenation reactions in planetary atmospheres may have played an important role for the reduction of simple carbon species such as $\mathrm{CO}_{2}$ and $\mathrm{CO}$, and for $\mathrm{CH}_{4}$ oxidation through dehydrogenation. In modern Earth's oxidizing atmosphere, hydrogenation of $\mathrm{CO}_{2}$ and $\mathrm{CO}$ rarely occurs, and thus is not well understood. On the other hand, in reducing atmospheres, potentially like that of the early Earth and Mars, hydrogenation of $\mathrm{CO}_{2}$ and $\mathrm{CO}$ could be initiated from UV photo-dissociation of $\mathrm{H}_{2} \mathrm{O}$ and $\mathrm{CO}_{2}$ :

$$
\mathrm{H}_{2} \mathrm{O}+h v \rightarrow \mathrm{H}+\mathrm{OH}
$$

$$
\mathrm{CO}_{2}+h v \rightarrow \mathrm{CO}+\mathrm{O}
$$

where $h v$ represents $<200 \mathrm{~nm}$ ultraviolet light. The back reaction of R13 is very slow, and thus the oxidation of CO largely proceeds through the reaction with $\mathrm{OH}$ radical:

$$
\mathrm{CO}+\mathrm{OH} \rightarrow \mathrm{CO}_{2}+\mathrm{H}
$$

However, when the atmosphere is reducing, hydrogenation of $\mathrm{CO}$ could form formyl radical (HCO) and then formaldehyde (HCHO), mainly through the following reactions (Pinto et al. 1980):

$$
\begin{aligned}
& \mathrm{CO}+\mathrm{H}+\mathrm{M} \rightarrow \mathrm{HCO}+\mathrm{M} \\
& \mathrm{HCO}+\mathrm{HCO} \rightarrow \mathrm{HCHO}+\mathrm{CO}
\end{aligned}
$$

where $\mathrm{M}$ represents any third-body reaction partner.

Once the $\mathrm{HCO}$ and $\mathrm{HCHO}$ are formed, several successive radical chain reactions can occur. Several laboratory experiments have 
a)<smiles>O=C([O-])C=CC=C[PbH2+]</smiles>

$$
\text { b) } \mathrm{CO}_{2}+\mathrm{H}_{2} \stackrel{\mathrm{FDH}+\mathrm{Hyd}}{=} \mathrm{CO}_{2}+\mathrm{CO}+\mathrm{H}_{2} \mathrm{ODH}+\mathrm{CODH}
$$

FIGURE 5. Examples of enzymes and the hydrogenation chemistry they catalyze with $\mathrm{CO}_{2}$. (a) Metal-independent formate dehydrogenase (FDH) catalyzes reversible formate dehydration to $\mathrm{CO}_{2}$ via a transfer hydrogenation of the biological electron carrier $\mathrm{NAD}(\mathrm{P})^{+}$(Egorov et al. 1979; Popov and Lamzin 1994). (b) The hydrogen dependent carbon dioxide reductase (HDCR) is a protein complex consisting of hydrogenase (Hyd) and formate dehydrogenase (FDH) subunits that together catalyzes $\mathrm{CO}_{2}$ reduction to formate with electrons from $\mathrm{H}_{2}$ (e.g., in Acetobacterium woodii; Schuchmann and Müller 2013). (c) The FDH subunit of HDCR can also reduce $\mathrm{CO}_{2}$ through oxidation of $\mathrm{CO}$ to $\mathrm{CO}_{2}$ $\left(E^{0 \prime}=-520 \mathrm{mV}\right.$; Schuchmann and Müller 2013; Diender et al. 2015) via the carbon monoxide dehydrogenase (CODH). Except the metal-free $\mathrm{FDH}$, all these enzymes have in common a reliance on transition metal ions including $\mathrm{Mo}, \mathrm{W}, \mathrm{Fe}$, and $\mathrm{Ni}$, for catalysis (Schoepp-Cothenet et al. 2012; Schuchmann and Müller 2013; Maia et al. 2017).

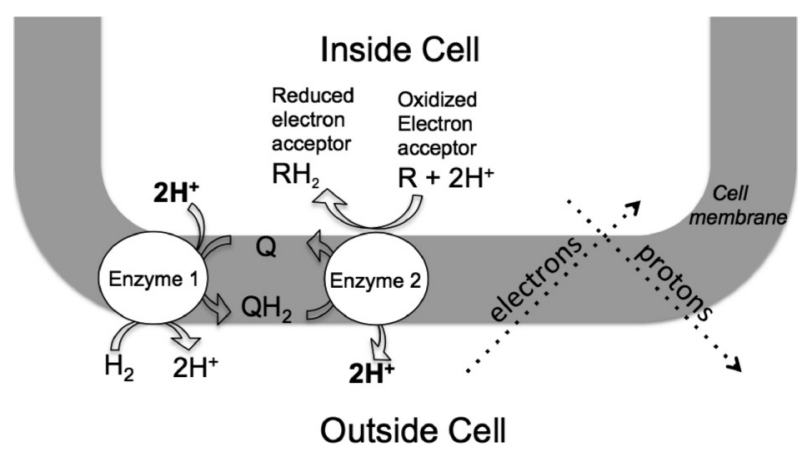

FIGURE 6. A "redox loop" mechanism coupling hydrogenation reactions to chemiosmosis in biology. Hydrogenation of quinol $(\mathrm{Q})$ inside the cell membrane (gray) by $\mathrm{H}_{2}$, and subsequent trans-hydrogenation of an intracellular electron acceptor (R), lead to charge separation across a biological membrane and the buildup of a chemiosmotic potential. Negative charge (electrons) goes in, positive charge (protons) go out. Variations on this theme are observed in biology; this figure represents one example as a starting point for deeper inquiry. The interested reader is directed to an excellent review (Simon et al. 2008).

demonstrated that not only formaldehyde, but also acetaldehyde, methanol, and carboxylic acids are synthesized by UV irradiation of CO-bearing atmosphere under the presence of water vapor (BarNun and Chang 1983; Kawade 2018). The reaction pathways to produce these compounds from $\mathrm{HCHO}$ is largely uncertain, though possibly proceed through the following reactions:

$$
\begin{aligned}
& \mathrm{HCHO}+\mathrm{OH} \rightarrow \mathrm{H}_{2} \mathrm{O}+\mathrm{HCO} \\
& \mathrm{HCHO}+\mathrm{OH} \rightarrow \mathrm{HCOOH}+\mathrm{H} \\
& \mathrm{HCHO}+\mathrm{H} \rightarrow \mathrm{H}_{2}+\mathrm{HCO} \\
& \mathrm{HCHO}+\mathrm{H}+\mathrm{M} \rightarrow \mathrm{CH}_{3} \mathrm{O}+\mathrm{M}
\end{aligned}
$$

$$
\mathrm{CH}_{3} \mathrm{O}+\mathrm{H}_{2} \rightarrow \mathrm{CH}_{3} \mathrm{OH}+\mathrm{H}
$$

These studies suggest that the abiotic synthesis of simple organic compounds is possible particularly when the $\mathrm{H} / \mathrm{OH}$ ratio is high (i.e., reducing atmosphere), because hydrogenation of $\mathrm{CO}$ (R15) is faster than the oxidation of CO (R14). Therefore, the production rate of these organics largely depends on total redox state of the atmosphere.

On early Earth and Mars, the most abundant and efficient reducing agent may have been $\mathrm{H}_{2}$ and possibly $\mathrm{CH}_{4}$, which can scavenge excess $\mathrm{OH}$ and thus buffer the reducing atmosphere. In an $\mathrm{H}_{2}$-rich and/or $\mathrm{CH}_{4}$-rich atmosphere, however, hydrogen escape into space is more efficient than oxidizing atmosphere. This is because $\mathrm{H}_{2}$ and $\mathrm{CH}_{4}$ are efficient carriers of hydrogen to the top of the atmosphere, whereas $\mathrm{H}_{2} \mathrm{O}$ is not, owing to condensation in the mid part of the atmosphere. Consequently, escape rate of hydrogen is high in a reducing atmosphere, which results in faster oxidation of the atmosphere in a geological timescale.

\section{IMPLICATIONS}

Abiotic reactions and their pathways involving hydrogenation/dehydrogenation can be challenging to identify due to the abundance of oxygen in geological fluids in the upper mantle, crust, and atmosphere. Several reactions mentioned in this article are rarely observed in natural settings as written, and they represent simplifications and/or intermediates of more complex aqueous solutions and reaction pathways. Exceptions may exist in settings where reducing conditions can be achieved and maintained over significant timescales. In the lithosphere, hydrothermal alteration of ultramafic rocks, or serpentinization, is certainly among the best candidates, even though our understanding of these systems is still largely incomplete and may incorporate other $\mathrm{H}_{2}$ generating processes such as radiolytic and mechanochemical splitting of water. Hydrogenation reactions in the deep Earth, such as in the mantle, may be more common because oxygen fugacity decreases with depth. Great effort is still demanded to understand hydrogenation/dehydrogenation processes and their role over the Earth's history. The potential outcomes of future research span critical features of science and modern society, such as global climate changes and the emergence/sustainability of life on our planet and beyond (Gurudayal et al. 2017). Over the past decade, experimental and theoretical studies have made great strides forward toward a better understanding of the past and present of geochemistry. In the coming decade, we should learn more about the impact of hydrogenation/dehydrogenation reactions on our planet and the mechanisms of their occurence.

\section{FUNDING}

S.E.M. is supported by NSF Award 1724300 and JSPS KAKENHI Grant JP18H01325. A.V.B. is supported by ANR T-ERC, CNRS INSU-SYSTER, and Rita Levi Montalcini by MIUR. J.B.G. is supported by NASA Exobiology Grant NNX14AJ87G and 80NSSC19K0477. F.K. is supported by NSF-OCE award 1634032 and 1427274 . M.O.S. is supported by the NASA Astrobiology Institute Rock-Powered Life Grant NNA15BB02A.

\section{REFERENCES CITED}

Allen, D.E., and Seyfried, W.E. (2003) Compositional controls on vent fluids from ultramafic-hosted hydrothermal systems at mid-ocean ridges: An experimental study at $400^{\circ} \mathrm{C}, 500$ bars. Geochimica et Cosmochimica Acta, 67, 1531-1542. 
Anderson, R.B. (1978) Schulz-Flory equation. Journal of Catalysis, 55, 114-115.

Appel,A.M., Bercaw, J.E., Bocarsly, A.B., Dobbek, H., DuBois, D.L., Dupuis, M., Ferry, J.G., Fujita, E., Hille, R., Kenis, P.J.A., and others. (2013) Frontiers, opportunities, and challenges in biochemical and chemical catalysis of $\mathrm{CO}_{2}$ fixation. Chemical Reviews, 113, 6621-6658.

Baldauf-Sommerbauer, G., Lux, S., Aniser, W., and Siebenhofer, M. (2016) Reductive Calcination of mineral magnesite: Hydrogenation of carbon dioxide without catalysts. Chemical Engineering \& Technology, 39, 2035-2041.

Bali, E., Audétat, A., and Keppler, H. (2013) Water and hydrogen are immiscible in Earth's mantle. Nature, 495, 220-222.

Bar-Nun, A., and Chang, S. (1983) Photochemical reactions of water and carbon monoxide in Earth's primitive atmosphere. Journal of Geophysical Research: Oceans, 88, 6662-6672.

Barton, L.L., Ed. (1995) Sulfate-Reducing Bacteria, 1st ed., 352 p. Springer.

Barton, L.L., and Fauque, G.D. (2009) Biochemistry, physiology and biotechnology of sulfate-reducing bacteria. Advances in Applied Microbiology, 68, 41-98.

Beller, M., and Bornscheuer, U.T. (2014) $\mathrm{CO}_{2}$ fixation through hydrogenation by chemical or enzymatic methods. Angewandte Chemie International Edition, 53, 4527-4528.

Bender, G., Pierce, E., Hill, J.A., Darty, J.E., and Ragsdale, S.W. (2011) Metal centers in the anaerobic microbial metabolism of $\mathrm{CO}$ and $\mathrm{CO}_{2}$. Metallomics: Integrated Biometal Science, 3, 797-815.

Brandes, J.A., Boctor, N.Z., Cody, G.D., Cooper, B.A., Hazen, R.M., and Yoder, H.S. (1998) Abiotic nitrogen reduction on the early Earth. Nature, 395, 365-367.

Bulen, W.A., and LeComte, J.R. (1966) The nitrogenase system from Azotobacter: two-enzyme requirement for $\mathrm{N}_{2}$ reduction, ATP-dependent $\mathrm{H}_{2}$ evolution, and ATP hydrolysis. Proceedings of the National Academy of Sciences, 56, 979-986.

Cadle, R.D. (1980) A comparison of volcanic with other fluxes of atmospheric trace gas constituents. Reviews of Geophysics, 18, 746-752.

Charlou, J.L., Donval, J.P., Fouquet, Y., Jean-Baptiste, P., and Holm, N. (2002) Geochemistry of high $\mathrm{H}_{2}$ and $\mathrm{CH}_{4}$ vent fluids issuing from ultramafic rocks at the Rainbow hydrothermal field ( $36^{\circ} 14^{\prime} \mathrm{N}$, MAR). Chemical Geology, 191, 345-359.

Cody, G.D., Boctor, N.Z., Filley, T.R., Hazen, R.M., Scott, J.H., Sharma, A., and Yoder, H.S. (2000) Primordial carbonylated iron-sulfur compounds and the synthesis of pyruvate. Science, 289, 1337-1340.

Connolly, J.A.D. (1995) Phase diagram methods for graphitic rocks and application to the system $\mathrm{C}-\mathrm{O}-\mathrm{H}-\mathrm{FeO}-\mathrm{TiO}_{2}-\mathrm{SiO}_{2}$. Contributions to Mineralogy and Petrology, 119, 94-116.

Deines, P. (1980) The isotropic composition of reduced organic carbon. In P. Fritz and J. Fontes, Eds., Handbook of Environmental Isotope Geology, vol. 1, p. 329-406. Elsevier.

Diender, M., Stams, A.J.M., and Sousa, D.Z. (2015) Pathways and Bioenergetics of Anaerobic Carbon Monoxide Fermentation. Frontiers in Microbiology, 6, 1275. doi: $10.3389 /$ fmicb. 2015.01275 .

Duszenko, N., and Buan, N.R. (2017) Physiological evidence for isopotential tunneling in the electron transport chain of methane-producing Archaea. Applied and Environmental Microbiology, 83.

Egorov, A.M., Avilova, T.V., Dikov, M.M., Popov, V.O., Rodionov, Y.V., and Berezin, I.V. (1979) NAD-dependent formate dehydrogenase from methylotrophic bacterium, strain. 1. Purification and characterization. European Journal of Biochemistry, 99, 569-576.

Escario, S., Godard, M., Gouze, P., and Leprovost, R. (2018) Experimental study of the effects of solute transport on reaction paths during incipient serpentinization. Lithos, 323, 191-207.

Etiope, G., and Lollar, B.S. (2013) Abiotic methane on Earth. Reviews of Geophysics, $51,276-299$.

Ferry, J.G. (1990) Formate dehydrogenase. FEMS Microbiology Reviews, 7, 377-382.

Ferry, J.G., and House, C.H. (2006) The stepwise evolution of early life driven by energy conservation. Molecular Biology and Evolution, 23, 1286-1292.

Gadalla,A.M., and Bower, B. (1988) The role of catalyst support on the activity of nickel for reforming methane with $\mathrm{CO}_{2}$. Chemical Engineering Science, 43, 3049-3062.

Giardini, A.A., and Salotti, C.A. (1969) Kinetics and relations in the calcite-hydrogen reaction and relations in the dolomite-hydrogen and siderite-hydrogen systems. American Mineralogist, 54, 1151-1172.

Goethel, P.J., and Yang, R.T. (1988) Mechanism of graphite hydrogenation catalyzed by ruthenium particles. Journal of Catalysis, 111, 220-226.

Goldstein, T.P., and Aizenshtat, Z. (1994) Thermochemical sulfate reduction a review. Journal of Thermal Analysis, 42, 241-290.

Griffin, W.L., Huang, J.-X., Thomassot, E., Gain, S.E.M., Toledo, V., and O'Reilly, S.Y. (2018) Super-reducing conditions in ancient and modern volcanic systems: sources and behaviour of carbon-rich fluids in the lithospheric mantle. Mineralogy and Petrology, 112, S101-S114.

Gurudayal, [no initial], Bullock, J., Srankó, D.F., Towle, C.M., Lum, Y., Hettick, M., Scott, M.C., Javey, A., and Ager, J. (2017) Efficient solar-driven electrochemical $\mathrm{CO}_{2}$ reduction to hydrocarbons and oxygenates. Energy \& Environmental Science, $10,2222-2230$.

Hattori, S. (2008) Syntrophic acetate-oxidizing microbes in methanogenic environments. Microbes and Environments, 23, 118-127.

He, C., Tian, G., Liu, Z., and Feng, S. (2010) A mild hydrothermal route to fix carbon dioxide to simple carboxylic acids. Organic Letters, 12, 649-651.
Hoehler, T.M., Alperin, M.J.,Albert, D.B., and Martens, C.S. (1994) Field and laboratory studies of methane oxidation in an anoxic marine sediment: Evidence for a methanogen-sulfate reducer consortium. Global Biogeochemical Cycles, 8, 451-463.

Hori, Y. (2008) Electrochemical $\mathrm{CO}_{2}$ reduction on metal electrodes. In C.G. Vayenas, R.E. White, and M.E. Gamboa-Aldeco, Eds., Modern Aspects of Electrochemistry, pp. 89-189. Springer.

Horita, J., and Berndt, M.E. (1999) Abiogenic methane formation and isotopic fractionation under hydrothermal Conditions. Science, 285, 1055-1057.

Huber, C., and Wächtershäuser, G. (1997) Activated acetic acid by carbon fixation on (Fe,Ni)S under primordial conditions. Science, 276, 245-247.

(1998) Peptides by activation of amino acids with $\mathrm{CO}$ on $(\mathrm{Ni}, \mathrm{Fe}) \mathrm{S}$ surfaces: Implications for the origin of life. Science, 281, 670-672.

Inskeep, W.P., Ackerman, G.G., Taylor, W.P., Kozubal, M., Korf, S., and Macur, R.E. (2005) On the energetics of chemolithotrophy in nonequilibrium systems: case studies of geothermal springs in Yellowstone National Park. Geobiology, 3, 297-317.

Johnson, J.E., Mienert, J., Plaza-Faverola, A., Vadakkepuliyambatta, S., Knies, J. Bünz, S., Andreassen, K., and Ferré, B. (2015) Abiotic methane from ultraslowspreading ridges can charge Arctic gas hydrates. Geology, 43(5), 371-374. https:// doi.org/10.1130/G36440.1

Jószai, I., and Joó, F. (2007) Hydrogenation of calcium carbonate in aqueous systems catalyzed by $\mathrm{Rh}(\mathrm{I})$ - and $\mathrm{Ru}(\mathrm{II})$-complexes using poly(methylhydrosiloxane) or hypophosphite as hydrogen sources. Reaction Kinetics and Catalysis Letters, 91 , 361-368.

Kawade, W. (2018) Experimental study on UV synthesis of organic compounds from $\mathrm{CO}$ and $\mathrm{CO}_{2}$ atmosphere, pp. 56. MSc thesis, Tokyo Institute of Technology.

Kawasumi, T., Igarashi, Y., Kodama, T., and Minoda, Y. (1980) Isolation of strictly thermophilic and obligately autotrophic hydrogen bacteria. Agricultural and Biological Chemistry, 44, 1985-1986.

Kitadai, N., Nakamura, R., Yamamoto, M., Takai, K., Li, Y., Yamaguchi, A., Gilbert, A., Ueno, Y., Yoshida, N., and Oono, Y. (2018) Geoelectrochemical CO production: Implications for the autotrophic origin of life. Science Advances, 4, eaao7265.

Klein, F., and Bach, W. (2009) Fe-Ni-Co-O-S phase relations in peridotite-seawater interactions. Journal of Petrology, 50, 37-59.

Klein, F., Bach, W., and McCollom, T.M. (2013) Compositional controls on hydrogen generation during serpentinization of ultramafic rocks. Lithos, 178, 55-69.

Klein, F., Grozeva, N.G., Seewald, J.S., McCollom, T.M., Humphris, S.E., Moskowitz, B., Berquó, T.S., and Kahl, W.-A. (2015) Experimental constraints on fluid-rock reactions during incipient serpentinization of harzburgite. American Mineralogist, $100,991-1002$.

Klein, F., Grozeva, N.G., and Seewald, J.S. (2019) Abiotic methane synthesis and serpentinization in olivine-hosted fluid inclusions. Proceedings of the National Academy of Sciences, 116, 17,666-17,672.

Lai, G.Y. (2007) High-temperature Corrosion and Materials Applications, 461 p. ASM International.

Lamadrid, H.M., Rimstidt, J.D., Schwarzenbach, E.M., Klein, F., Ulrich, S., Dolocan, A., and Bodnar, R.J. (2017) Effect of water activity on rates of serpentinization of olivine. Nature Communications, 8, 16107.

Lang, S.Q., Früh-Green, G.L., Bernasconi, S.M., Lilley, M.D., Proskurowski, G., Méhay, S., and Butterfield, D.A. (2012) Microbial utilization of abiogenic carbon and hydrogen in a serpentinite-hosted system. Geochimica et Cosmochimica Acta, 92, 82-99.

Lang, S.Q., Früh-Green, G.L., Bernasconi, S.M., Brazelton, W.J., Schrenk, M.O., and McGonigle, J.M. (2018) Deeply-sourced formate fuels sulfate reducers but not methanogens at Lost City hydrothermal field. Scientific Reports, 8, 1-10.

Lazar, C., Zhang, C., Manning, C.E., and Mysen, B.O. (2014) Redox effects on calciteportlandite-fluid equilibria at forearc conditions: Carbon mobility, methanogenesis, and reduction melting of calcite. American Mineralogist, 99, 1604-1615.

Lux, S., Baldauf-Sommerbauer, G., and Siebenhofer, M. (2018) Hydrogenation of inorganic metal carbonates: A review on its potential for carbon dioxide utilization and emission reduction. ChemSusChem, 11, 3357-3375.

Maden, B.E. (2000) Tetrahydrofolate and tetrahydromethanopterin compared: functionally distinct carriers in $\mathrm{C} 1$ metabolism. The Biochemical Journal, 350, 609-629.

Maia, L.B., Moura, I., and Moura, J.J.G. (2017) Molybdenum and tungsten-containing formate dehydrogenases: Aiming to inspire a catalyst for carbon dioxide utilization. Inorganica Chimica Acta, 455, 350-363.

Malvoisin, B., and Brunet, F. (2014) Water diffusion-transport in a synthetic dunite: Consequences for oceanic peridotite serpentinization. Earth and Planetary Science Letters, 403, 263-272.

Martin, B., and Fyfe, W.S. (1970) Some experimental and theoretical observations on the kinetics of hydration reactions with particular reference to serpentinization. Chemical Geology, 6, 185-202.

Mayhew, S.G. (1978) The redox potential of dithionite and $\mathrm{SO}^{-2}$ from equilibrium reactions with flavodoxins, methyl viologen and hydrogen plus hydrogenase. European Journal of Biochemistry, 85, 535-547.

McCollom, T.M. (2003) Formation of meteorite hydrocarbons from thermal decomposition of siderite $\left(\mathrm{FeCO}_{3}\right)$. Geochimica et Cosmochimica Acta, 67, 311-317.

(2016) Abiotic methane formation during experimental serpentinization of olivine. Proceedings of the National Academy of Sciences, 113, 13965-13970.

McCollom, T.M., and Bach, W. (2009) Thermodynamic constraints on hydrogen generation during serpentinization of ultramafic rocks. Geochimica et Cosmochimica Acta, 73, 856-875. 
McDermott, J.M., Seewald, J.S., German, C.R., and Sylva, S.P. (2015) Pathways for abiotic organic synthesis at submarine hydrothermal fields. Proceedings of the National Academy of Sciences, 112, 7668-7672.

McGlynn, S.E. (2017) Energy metabolism during anaerobic methane oxidation in ANME Archaea. Microbes and Environments, 32, 5-13.

Miao, B., Ma, S.S.K., Wang, X., Su, H., and Chan, S.H. (2016) Catalysis mechanisms of $\mathrm{CO}_{2}$ and $\mathrm{CO}$ methanation. Catalysis Science \& Technology, 6, 4048-4058.

Mielke, R.E., Russell, M.J., Wilson, P.R., McGlynn, S.E., Coleman, M., Kidd, R., and Kanik, I. (2010) Design, fabrication, and test of a hydrothermal reactor for originof-life experiments. Astrobiology, 10, 799-810.

Muchowska, K.B., Varma, S.J., Chevallot-Beroux, E., Lethuillier-Karl, L., Li, G., and Moran, J. (2017) Metals promote sequences of the reverse Krebs cycle. Nature Ecology \& Evolution, 1, 1716.

Nakajima, T., Yabushita, Y., and Tabushi, I. (1975) Amino acid synthesis through biogenetic-type $\mathrm{CO}_{2}$ fixation. Nature, 256, 60-61.

Nie, X., Esopi, M.R., Janik, M.J., and Asthagiri, A. (2013) Selectivity of CO(2) reduction on copper electrodes: the role of the kinetics of elementary steps. Angewandte Chemie (International), 52, 2459-2462. (in English)

Nitschke, W., and Russell, M.J. (2009) Hydrothermal focusing of chemical and chemiosmotic energy, supported by delivery of catalytic $\mathrm{Fe}, \mathrm{Ni}, \mathrm{Mo} / \mathrm{W}, \mathrm{Co}, \mathrm{S}$ and $\mathrm{Se}$, forced life to emerge. Journal of Molecular Evolution, 69, 481-496.

Padeste, C., Oswald, H.R., and Reller, A. (1991) The thermal behaviour of pure and nickel-doped hydromagnesite in different atmospheres. Materials Research Bulletin, 26, 1263-1268.

Perry, E.C., and Ahmad, S.N. (1977) Carbon isotope composition of graphite and carbonate minerals from 3.8-AE metamorphosed sediments, Isukasia, Greenland. Earth and Planetary Science Letters, 36, 280-284.

Pinto, J.P., Gladstone, G.R., and Yung, Y.L. (1980) Photochemical production of formaldehyde in Earth's primitive atmosphere. Science, 210, 183-185.

Popov, V.O., and Lamzin, V.S. (1994) NAD(+)-dependent formate dehydrogenase. Biochemical Journal, 301, 625-643.

Preiner, M., Xavier, J.C., Sousa, F.L., Zimorski, V., Neubeck, A., Lang, S.Q., Greenwell, H.C., Kleinermanns, K., Tüysüz, H., McCollom, T.M., and others (2018) Serpentinization: Connecting geochemistry, ancient metabolism and industrial hydrogenation. Life, 8, 41 (22 p.). DOI https://doi.org/10.3390/life8040041

Proskurowski, G., Lilley, M.D., Seewald, J.S., Früh-Green, G.L., Olson, E.J., Lupton, J.E., Sylva, S.P., and Kelley, D.S. (2008) Abiogenic hydrocarbon production at lost city hydrothermal field. Science, 319, 604-607.

Reller, A., Emmenegger, R., Padeste, C., and Oswald, H.-R. (1991) Thermochemical reactivity of metal carbonates. Chimia International Journal for Chemistry, 45, 262-266.

Rönsch, S., Schneider, J., Matthischke, S., Schlüter, M., Götz, M., Lefebvre, J., Prabhakaran, P., and Bajohr, S. (2016) Review on methanation-From fundamentals to current projects. Fuel, 166, 276-296.

Rumble, D., and Hoering, T.C. (1986) Carbon isotope geochemistry of graphite vein deposits from New Hampshire, U.S.A. Geochimica et Cosmochimica Acta, 50, 1239-1247.

Russell, M.J., and Martin, W. (2004) The rocky roots of the acetyl-CoA pathway. Trends in Biochemical Sciences, 29, 358-363.

Sabatier, P., and Senderens, J. (1902) New synthesis of methane. Comptes Rendus Chimie, 134, 514-516.

Salotti, C.A., Heinrich, E.W., and Giardini, A.A. (1971) Abiotic carbon and the formation of graphite deposits. Economic Geology, 66, 929-932.

Schoepp-Cothenet, B., van Lis, R., Philippot, P., Magalon, A., Russell, M.J., and Nitschke, W. (2012) The ineluctable requirement for the trans-iron elements molybdenum and/or tungsten in the origin of life. Scientific Reports, 2.

Schoonen, M.A.A., and Xu, Y. (2001) Nitrogen reduction under hydrothermal vent conditions: Implications for the prebiotic synthesis of C-H-O-N compounds. Astrobiology, 1, 133-142.

Schuchmann, K., and Müller, V. (2013) Direct and reversible hydrogenation of $\mathrm{CO}_{2}$ to formate by a bacterial carbon dioxide reductase. Science, 342, 1382-1385.

(2014) Autotrophy at the thermodynamic limit of life: a model for energy conservation in acetogenic bacteria. Nature Reviews. Microbiology, 12, 809-821.

Seewald, J.S., Zolotov, M.Yu., and McCollom, T. (2006) Experimental investigation of single carbon compounds under hydrothermal conditions. Geochimica et Cos- mochimica Acta, 70, 446-460.

Simon, J., van Spanning, R.J.M., and Richardson, D.J. (2008) The organisation of proton motive and non-proton motive redox loops in prokaryotic respiratory systems. Biochimica et Biophysica Acta, 1777, 1480-1490.

Smirnov, A., Hausner, D., Laffers, R., Strongin, D.R., and Schoonen, M.A. (2008) Abiotic ammonium formation in the presence of Ni-Fe metals and alloys and its implications for the Hadean nitrogen cycle. Geochemical Transactions, 9, 5 .

Smit, K.V., Shirey, S.B., Stern, R.A., Steele, A., and Wang, W. (2016) Diamond growth from $\mathrm{C}-\mathrm{H}-\mathrm{N}-\mathrm{O}$ recycled fluids in the lithosphere: Evidence from $\mathrm{CH}_{4}$ micro-inclusions and $\delta^{13} \mathrm{C}-\delta^{15} \mathrm{~N}-\mathrm{N}$ content in Marange mixed-habit diamonds. Lithos, C, 68-81.

Spear, J.R., Walker, J.J., McCollom, T.M., and Pace, N.R. (2005) Hydrogen and bioenergetics in the Yellowstone geothermal ecosystem. Proceedings of the Nationa Academy of Sciences, 102, 2555-2560.

Syverson, D.D., Tutolo, B.M., Borrok, D.M., and Seyfried, W.E. (2017) Serpentinization of olivine at $300^{\circ} \mathrm{C}$ and 500 bars: An experimental study examining the role of silica on the reaction path and oxidation state of iron. Chemical Geology, 475, 122-134.

Tao, R., Zhang, L., Tian, M., Zhu, J., Liu, X., Liu, J., Höfer, H.E., Stagno, V., and Fei, Y. (2018) Formation of abiotic hydrocarbon from reduction of carbonate in subduction zones: Constraints from petrological observation and experimental simulation. Geochimica et Cosmochimica Acta, 239, 390-408.

Thauer, R.K. (1998) Biochemistry of methanogenesis: a tribute to Marjory Stephenson. 1998 Marjory Stephenson Prize Lecture. Microbiology (Reading, England), 144 (Pt 9), 2377-2406.

(2010) Functionalization of methane in anaerobic microorganisms. Angewandte Chemie (International), 49, 6712-6713. (in English)

(2011) Anaerobic oxidation of methane with sulfate: on the reversibility of the reactions that are catalyzed by enzymes also involved in methanogenesis from $\mathrm{CO}_{2}$. Current Opinion in Microbiology, 14, 292-299.

Thauer, R.K., Jungermann, K., and Decker, K. (1977) Energy conservation in chemotrophic anaerobic bacteria. Bacteriological Reviews, 41, 100-180.

Thauer, R.K., Kaster, A.-K., Seedorf, H., Buckel, W., and Hedderich, R. (2008) Methanogenic archaea: ecologically relevant differences in energy conservation. Nature Reviews. Microbiology, 6, 579-591.

Thomassot, E., Cartigny, P., Harris, J.W., and (Fanus) Viljoen, K.S. (2007) Methanerelated diamond crystallization in the Earth's mantle: Stable isotope evidences from a single diamond-bearing xenolith. Earth and Planetary Science Letters, 257, 362-371.

Tsuneto, A., Kudo, A., Saito, N., and Sakata, T. (1992) Hydrogenation of solid state carbonates. Chemistry Letters, 21, 831-834.

Varma, S.J., Muchowska, K.B., Chatelain, P., and Moran, J. (2018) Native iron reduces $\mathrm{CO}_{2}$ to intermediates and end-products of the acetyl-CoA pathway. Nature Ecology \& Evolution, 2, 1019.

Vitale Brovarone, A., Martinez, I., Elmaleh, A., Compagnoni, R., Chaduteau, C., Ferraris, C., and Esteve, I. (2017) Massive production of abiotic methane during subduction evidenced in metamorphosed ophicarbonates from the Italian Alps. Nature Communications, 8, 14134.

Wang, D.T., Reeves, E.P., McDermott, J.M., Seewald, J.S., and Ono, S. (2018) Clumped isotopologue constraints on the origin of methane at seafloor hot springs. Geochimica et Cosmochimica Acta, 223, 141-158.

Wei, J., Ge, Q., Yao, R., Wen, Z., Fang, C., Guo, L., Xu, H., and Sun, J. (2017) Directly converting $\mathrm{CO} 2$ into a gasoline fuel. Nature Communications, 8, 15174

Welhan, J.A. (1988) Origins of methane in hydrothermal systems. Chemical Geology, 71, 183-198.

Yamaguchi, A., Yamamoto, M., Takai, K., Ishii, T., Hashimoto, K., and Nakamura, R. (2014) Electrochemical $\mathrm{CO}_{2}$ reduction by Ni-containing iron sulfides: How is $\mathrm{CO}_{2}$ electrochemically reduced at bisulfide-bearing deep-sea hydrothermal precipitates? Electrochimica Acta, 141, 311-318.

Yoshida, N., Hattori, T., Komai, E., and Wada, T. (1999) Methane formation by metalcatalyzed hydrogenation of solid calcium carbonate. Catalysis Letters, 58, 119-122.

MANUSCRIPT RECEIVED DECEMBER 13, 2018

MANUSCRIPT ACCEPTED NOVEMBER 20, 2019

MANUSCRIPT HANDLED BY DONATO GIOVANNELLI 